\title{
REALISASI KESANTUNAN BERBAHASA DALAM PROSES BELAJAR MENGAJAR BAHASA INDONESIA KELAS XI SMK
}

\author{
Ade Jauhari \\ STIT NU Al Mahsuni Lombok Timur, NTB \\ email: adejauhari1990@gmail.com
}

\begin{abstract}
ABSTRAK
Tujuan penelitian ini untuk mendeskripsikan dan menganalisis wujud pematuhan prinsip, strategi dan fungsi kesantunan berbahasa guru dan siswa dalam proses belajar mengajar bahasa Indonesia kelas XI SMKN 2 Depok, Sleman, Yogyakarta. Penelitian ini merupakan penelitian deskriptif kualitatif. Pengumpulan data dilakukan dengan teknik simak bebas libat cakap, teknik rekam, dan teknik catat. Analisis data menggunakan metode padan ekstralingual. Hasil penelitian ini menunjukkan bahwa adanya pematuhan prinsip kesantunan berbahasa yang terdiri atas pematuhan satu maksim dan dua maksim. Pematuhan satu maksim meliputi: (1) kebijaksanaan, (2) kedermawanan, (3) pujian, (4) kerendahhatian, (5) kesetujuan, dan (6) kesimpatian. Pematuhan dua maksim meliputi: (1) kebijaksanaan dan pujian, (2) kebijaksanaan dan kedermawanan, (3) kebijaksanaan dan kesimpatian, (4) kebijaksanaan dan kesetujuan, (5) kedermawanan dan kerendahhatian, dan (6) pujian dan kerendahhatian. Strategi yang digunakan dalam merealisasikan kesantunan berbahasa meliputi strategi kesantunan positif dan strategi kesantunan negatif. Fungsi kesantunan berbahasa dalam proses belajar mengajar ini meliputi: (1) menyatakan, (2) menanyakan, (3) memerintah, (4) meminta maaf, dan (5) mengkritik.
\end{abstract}

Kata Kunci: kesantunan berbahasa, pembelajaran bahasa Indonesia

\section{THE REALIZATION OF LANGUAGE POLITENESS IN THE TEACHING AND LEARNING PROCESS OF BAHASA INDONESIA IN GRADE XI OF SMK}

\begin{abstract}
This study aims to describe the form of adherence principles, strategies, function of language politeness of the teachers and students in the teaching and learning of Bahasa Indonesia in grade XI SMKN 2 Depok, Sleman, Yogyakarta. This research was qualitative descriptive research. The data were collected through simak bebas libat cakap technique, recording technique, and note-taking technique. The data analysis used the ekstralingual identity method. The results of this research show that there is an adherence to the politeness consists of the adherence one maxim and two maxim. The adherence one maxim to: (1) the tact (2) the generosity, (3) the approbation, (4) the modesty, (5) the agreement, and (6) the sympathy. The adherence two maxim to: (1) the tact and approbation, (2) the tact and generosity, (3) the tact and sympathy, (4) the tact and agreement, (5) the generosity and modesty, (6) the approbation and modesty. The strategy used in the realization of linguistic politeness includethe positive politeness strategies and the negative politeness strategies. Politeness functions in the teaching-learning process include: (1) declaring, (2) inquiring, (3) governing, (4) apologizing, and (5) criticizing.
\end{abstract}

Keywords: language politeness, learning bahasa Indonesia

\section{PENDAHULUAN}

Bahasa merupakan alat komunikasi yang digunakan manusia untuk memahami maksud dari orang lain. Di dalam kehidupan bermasyarakat, bahasa dapat menunjukkan santun atau tidaknya seseorang dari cara mereka menggunakan bahasa tersebut. Seseorang dapat dilihat kesantunannya dari ucapan dan tingkah laku mereka ketika berkomunikasi dengan orang lain. Kesantunan dalam berbahasa 
dapat mencerminkan status sosial penggunanya. Halim, Kaseng, Taha, dan Hamsa (2015: 237) mengatakan bahwa status sosial masyarakat di Kabupaten Wajo mencerminkan atau tercermin dalam penggunaan kesantunan bahasa mereka, baik dari segi pendidikan, usia, pekerjaan, ekonomi, atau garis keturunan.

Kesantunan berbahasa merupakan salah satu aspek yang perlu mendapatkan perhatian lebih dalam komunikasi. Watts (2003: 48) menyatakan bahwa realisasi kesantunan berbahasa membahas bagaimana manusia menggunakan istilah-istilah yang tersedia dalam bahasa untuk mencapai kesantunan. Santun atau tidaknya suatu tuturan bergantung dari indikator yang berlaku dalam suatu masyarakat. Tuturan yang dianggap santun dalam bahasa Indonesia secara umum jika mengandung kata-kata yang halus, tidak mengandung ejekan, tidak memerintah secara langsung, serta menghormati orang lain. Salah satu indikator dalam menentukan santun atau tidaknya tuturan dalam komunikasi adalah terpenuhinya maksim-maksim kesantunan dalam tuturan tersebut. Semakin terpenuhinya maksimmaksim kesantunan dalam tuturan, maka tuturan tersebut dianggap semakin santun.

Dalam interaksi sosial sehari-hari, penutur harus menjaga agar percakapan berjalan dengan lancar dan hubungan antara peserta komunikasi tidak terganggu. Untuk mengujudkan ini, penerapan kesantunan berbahasa sangatlah penting dalam percakapan. Tujuannya adalah untuk menciptakan keharmonisan hubungan antara peserta komunikasi yang terlibat. Malhari (2015: 7) dalam penelitiannya yang berjudul Importance of Politeness Principle menjelaskan bahwa kesantunan dapat meningkatkan saling pengertian dan menciptakan hubungan harmonis antara peserta komunikasi. Selain itu Malhari juga mendapat kesimpulan bahwa kesantunan berkontribusi terciptanya interaksi yang efektif, ramah dan nyaman di masyarakat. Pendapat ini juga diperkuat dengan penelitian Aziz (2005: 212) yang berkesimpulan bahwa realisasi kesantunan berbahasa lebih diarahkan pada upaya menjaga keharmonisan sesama warga masyarakat dan penjagaan citra diri di hadapan mitra tutur terlebih-lebih di antara sesama sahabat dekat, tetangga, atau tamu asing. Hal ini berarti kesantunan berbahasa sangatlah perlu diperhatikan dalam proses komunikasi di dalam masyarakat.

Penerapan kesantunan berbahasa muncul di berbagai segi kehidupan sosial, seperti pendidikan, perkantoran, keagamaan, pemerintahan, kemasyarakatan, media, keluarga, dan di dunia bisnis pun muncul penerapan kesantunan berbahasa ini. Penerapan kesantunan berbahasa ini sangat pantas untuk mendapat perhatian utama di dunia pendidikan terutama saat proses pembelajaran di kelas berlangsung. Kumar, Philip, dan Kalaiselvi (2013: 25) mengatakan bahwa pengajaran Bahasa Komunikatif tidak hanya menganggap bahasa dalam hal struktur tata bahasa dan kosa kata, tetapi juga dari segifungsikomunikatifyang dilakukan. Dengan kata lain, pengajaran bahasa harus juga menekankan bagaimana bahasa itu digunakan untuk berkomunikasi di kehidupan sosial. Di sinilah peran guru terutama guru bahasa Indonesia untuk mengajarkan dan sebagai panutan bagi peserta didik dalam menggunakan bahasa yang baik, benar dan santun untuk diterapkan dalam kehidupan sosial.

Tindak tutur kesantunan berbahasa merupakan alat yang sangat tepat diterapkan dalam interaksi percakapan, terutama dalam interaksi percakapan guru dan siswa pada saat kegiatan pembelajaran di dalam kelas. Hal ini didapatkan dari penelitian Rahadini dan Suwarna (2014: 143) yang berkesimpulan bahwa penggunaan bentuk-bentuk kesantunan berbahasa Jawa baik oleh guru dan siswa untuk menyamankan dan memperlancar komunikasi dan interaksi dalam pembelajaran. Tuturan guru memilki peranan yang sangat penting dalam kegiatan pembelajaran.

Guru lebih banyak menggunakan tuturan lisan untuk menyampaikan materi kepada siswa. Oleh sebab itu, tuturan guru memegang peranan sentral dalam mengembangkan intelektual siswa dan merupakan kunci untuk siswa dalam memahami materi yang disampaikan oleh guru. Melihat begitu pentingnya tuturan guru ini, maka guru terutama guru bahasa Indonesia selain harus mampu menggunakan bahasa yang baik dan benar, seorang guru juga harus mampu menggunakan bahasa yang santun untuk bertindak tutur dengan siswanya. Dalam kenyataannya guru kurang memiliki pengetahuan awal tentang 
aspek-aspek kesantunan berbahasa ini, oleh karena itu penelitian ini lebih memfokuskan pada pengenalan awal mengenai kesantunan berbahasa. Untuk itu penelitian ini merumuskan permasalahan terhadap wujud pematuhan prinsip, strategi dan fungsi kesantunan berbahasa dalam proses belajar mengajar. Penelitian ini bertujuan untuk mendeskripsikan dan menganalisis wujud pematuhan prinsip, strategi dan fungsi kesantunan berbahasa.

Kesantunan berbahasa memiliki peranan yang sangat penting dalam pembentukan sikap dan karakter peserta didik. Kesantunan berbahasa peserta didik dapat dijadikan sebagai salah satu barometer dari kesantunan sikapnya secara keseluruhan serta kepribadian dan budi pekerti yang dimilikinya. Bagi peserta didik yang menempuh pendidikan SMK, kesantunan berbahasa menjadi sangatlah penting jika dikuasai. Hal ini dikarenakan peserta didik yang berpendidikan SMK diharapkan untuk masuk dan mampu bersaing di dunia kerja. Di dalam dunia kerja, keterampilan berbahasa khususnya kemampuan berbahasa dengan santun wajib untuk dikuasai peserta didik guna bersaing di dunia kerja. Pembelajaran bahasa Indonesia dalam hal ini memegang peranan yang besar dalam membentuk sikap berbahasa peserta didik, terutama dalam hal berbahasa santun. Maka dari itu, pembelajaran bahasa Indonesia haruslah memperhatikan aspek kesantunan berbahasa, terutama dalam proses belajar mengajar di dalam kelas.

Berdasarkan wacana dan pertimbangan pentingnya kesantunan berbahasa dalam proses belajar mengajar seperti uraian tersebut, maka peneliti tertarik untuk meneliti permasalahan "Realisasi Kesantunan Berbahasa dalam Proses Belajar Mengajar Kelas XI SMK"

\section{METODE}

Jenis penelitian ini adalah penelitian deskriptif kualitatif. Pemilihan jenis penelitian ini sesuai dengan tujuan penelitian yang ingin mendeskripsikan dan menganalisis wujud pematuhan prinsip, strategi dan fungsi kesantunan berbahasa guru dan siswa dalam proses belajar mengajar bahasa Indonesia kelas XI SMKN 2 Depok, Sleman.
Penelitian ini dilakukan di SMKN 2 Depok Sleman Yogyakarta kelas XI karena mempertimbangkan kualitas sekolah dan peserta didik. Waktu penelitian dimulai pada bulan Januari sampai bulan Maret tahun 2016.

Subjek penelitian ini adalah peristiwa berbahasa guru dan siswa dalam proses belajar mengajar bahasa Indonesia kelas XI SMKN 2 Depok Sleman Yogyakarta. Subyek penelitian ini mengamati peristiwa berbahasa guru Bahasa Indonesia dengan usia sekitar 45-50 tahun, bergender laki-laki, dengan tingkat jenjang strata satu. kajian ini memilih peristiwa berbahasa siswa kelas XI dengan tiga jurusan berbeda, yaitu jurusan tekhnik komputer jaringan, tekhnik gambar bangunan dan tekhnik audio video. Subyek penelitian ini diamati dalam delapan kali proses belajar mengajar dengan lima topik pembelajaran, yaitu teks eksplanasi, menyunting teks eksplanasi, teks ulasan film atau drama, struktur teks ulasan film atau drama, dan kaidah kebahasaan teks ulasan film atau drama. Adapun yang menjadi objek dari penelitian ini adalah realisasi kesantunan berbahasa pada tuturan guru dan siswa dalam proses belajar mengajar bahasa Indonesia kelas XI SMKN 2 Depok Sleman Yogyakarta.

Instrumen penelitian yang digunakan dalam penelitian ini adalah peneliti sendiri ( $h u-$ man instrument). Peneliti juga menggunakan parameter kesantunan untuk mengetahui sebuah tuturan menaati prinsip kesantunan. Indikatorindikator tersebut disusun berdasarkan indikator yang disusun Leech (1993), Zamzani, Musfiroh, Maslakhah, Listyorini, dan Eny. (2011), Pranowo (2012) Rahardi (2007) dan Chaer (2010) yang kemudian dibagi dalam maksim-maksim yang mendasarinya.

Metode pengumpulan data pada penelitian ini menggunakan metode simak dengan tiga teknik utama, yaitu pertama teknik simak bebas libat cakap. Dalam teknik simak bebas libat cakap, penulis berperan sebagai penyimak penggunaan bahasa tanpa ikut berpartisipasi di dalamnya (Mahsun, 2005: 93). Penulis dalam teknik simak libas cakap ini tidak bertindak sebagai pembicara yang berhadapan langsung dengan mitra wicara. Dengan kata lain, penulis sebagai pendengar mitra wicara, memperhatikan apa yang dikatakan oleh penutur yang terlibat 
dalam dialog ketika proses belajar mengajar berlangsung. Teknik kedua yang digunakan dalam penelitian ini yaitu teknik rekam. Ketika teknik pertama digunakan, peneliti sekaligus melakukan perekaman dengan alat bantu rekam video berupa kamera digital. Teknik ketiga yang digunakan dalam penelitian ini adalah teknik catat. Selama kedua teknik di atas dilaksanakan, penulis juga melakukan catatan lapangan sebagai alat untuk mengingat kejadian pada saat proses belajar mengajar berlangsung, baik yang didengar maupun yang dilihat.

Analisis data menggunakan metode padan. teknik padan yang digunakan dalam penelitian ini adalah teknik padan ekstralingual, yaitu teknik analisis data yang alat penentunya adalah unsur di luar bahasa dan tidak menjadi bagian dari bahasa yang bersangkutan, misalnya penutur, lawan tutur, konteks tuturan, dan lain-lain. Tahapan analisis data meliputi tahap reduksi data, penyajian data, dan kesimpulan.

\section{HASIL DAN PEMBAHASAN Wujud Pematuhan Prinsip Kesantunan Ber- bahasa Guru dan Siswa}

Wujud pematuhan prinsip kesantunan berbahasa guru dan siswa yang ditemukan dalam penelitian ini adalah wujud pematuhan satu maksim dan dua maksim. Pematuhan satu maksim meliputi maksim kebijaksanaan, maksim pujian, maksim kedermawanan, maksim kerendahhatian, maksim kesetujuan dan maksim simpati. Pematuhan dua maksim meliputi maksim kebijaksanaan dan pujian, maksim kebijaksanaan dan kedermawanan, maksim kebijaksanaan dan kesimpatian, maksim kebijaksanaan dan kesimpatian, maksim kedermawanan dan kerendahhatian, terakhir maksim pujian dan kerendahhatian. Setiap maksim diuraikan dalam berikut ini.

Maksim kebijaksanaan menuntut penutur untuk selalu memaksimalkan keuntungan mitra tutur dan meminimalkan kerugian mitra tutur. Pematuhan maksim kebijaksanaan dalam tuturan guru dan siswa dapat ditunjukkan dalam contoh data (1) berikut.

(1) Guru: "Sudah selesai belum mencatatnya?" Siswa: "Belum Pak."

Guru: "Dipercepat sedikit ya, setelah ini bapak akan jelaskan ya."
Data (1) Dituturkan ketika guru meminta siswa untuk mempercepat menyelesaikan tulisan saat siswa menulis materi. Data (1) termasuk ke dalam pematuhan maksim kebijaksanaan karena tuturan guru meminimalkan kerugian dari siswa. Peminimalan kerugian ditunjukkan dari penggunaan kata "sedikit" dan penggunaan tuturan memerintah dengan nada pertanyaan. Penggunaan kata "sedikit" untuk mengurangi kerugian siswa jika harus menyelesaikan tulisan secara cepat dan terburu-buru. Penggunaan tuturan bernada pertanyaan ini akan mengurangi paksaan dari tuturan perintah guru. Hal ini sesuai dengan kategori berbahasa sangat santun menurut indikator kesantunan Zamzani, Musfiroh, Maslakhah, Listyorini, dan Eny (2011: 42) dalam jurnal Litera.

Maksim kedermawanan menuntut penutur untuk membuat keuntungan pada diri sendiri sekecil mungkin dan membuat kerugian pada diri sendiri sebanyak mungkin dapat dilihat berikut ini.

(2) Siswa: Tok.. tok.. tok.. (suara pintu diketuk dari luar)

Guru: "Silahkan mas, sini, sini, ada yang bisa dibantu?" (siswa mencium tangan guru)

Siswa: "Mau pinjem laptop pak"

Data (2) Dituturkan guru ketika ada siswa kelas lain masuk saat sedang menjelaskan materi. Data (2) di atas guru memaksimalkan kerugian pada dirinya sendiri. Tuturan di atas dianggap santun karena guru mengijinkan siswa untuk memasuki kelas walaupun mengganggu proses belajar. Tuturan guru terdapat kata "silahkan" untuk memberikan ijin kepada siswa untuk memasuki kelas. Kata silahkan yang dilekatkan pada awal tuturan dapat berfungsi sebagai penghalus tuturan (Rahardi, 2007: 127). Tuturan di atas dapat dilihat kedermawanan seorang guru karena walaupun terganggu, guru berusaha untuk menawarkan bantuan kepada siswa.

Maksim pujian menuntut untuk memberikan pujian sebanyak-banyaknya kepada lawan tutur dan memberikan cacian sesedikit mungkin kepada lawan tutur.

(3) Siswa 1: "Ya, mas Rahmad mau tanya apa?" 
Siswa 2: "Ya saya mau bertanya, terima kasih atas presentasinya, itu tornado sama puting beliung ada bedanya tidak? Terima kasih"

Data (3) Dituturkan ketika siswa 2 bertanya dalam sesi tanya jawab presentasi. Data (3) di atas, siswa 2 memberikan pujian dan penghargaan sebanyak-banyaknya kepada siswa 1. Pemberian penghargaan siswa 2 kepada siswa 1 ditunjukkan ketika sebelum memulai pertanyaan, siswa 2 mengucapkan "terima kasih atas presentasinya" dan siswa 2 menambah penghormatannya kepada siswa 1 ketika mengakhiri pertanyaan dengan mengucapkan "terima kasih". Hal ini sesuai dengan indikator tuturan santun yang dikemukakan Pranowo (2012: 104) yaitu menggunakan kata terima kasih sebagai penghormatan atas kebaikan seseorang.

Maksim kerendahhatian menuntut penutur untuk meminimalkan pujian bagi dirinya sendiri dan memaksimalkan cacian kepada dirinya sendiri.

(4) Siswa : “...Hanya ini yang bisa kami sampaikan, kurang lebihnya kami mohon maaf, assaalamualaikum warrohmatullah hiwabarokatuh"

Data (4) Dituturkan siswa ketika mengakhiri presentasi kelompok. Data (4) di atas, mampu memaksimalkan ketidakhormatan terhadap diri sendiri. Tuturan di atas terasa santun karena siswa mencoba untuk merendahkan diri dengan mengakhiri presentasi dengan kalimat "hanya ini yang bisa kami sampaikan, kurang lebihnya kami mohon maaf". Tuturan ini menunjukkan bahwa siswa yang presentasi merasa apa yang dipresentasikan masih ada kekurangan. Hal ini sesuai dengan indikator berbahasa sangat santun menurut Zamzani, Musfiroh, Maslakhah, Listyorini, dan Eny. (2011: 42) yaitu menunjukkan rasa rendah hati dan tidak sombong.

Maksim kesetujuan ini menuntut penutur untuk memaksimalkan kesetujuan dengan lawan tutur dan meminimalkan ketidaksetujuan dengan lawan tutur.

(5) Siswa: "Gunung yang dor" (siswa menyeletuk dan membuat siswa lain tertawa)

Guru: "Sudah bagus itu, gunung yang berbunyi dor pun masih menyambung, tetapi kalau paragraf satu, paragraf kedua itu yang membahas misalnya tentang sinar matahari itu kan tidak nyambung.."

Data (5) Dituturkan guru ketika sedang menjelaskan materi ada siswa menyeletuk kemudian membuat siswa lain tertawa. Data (5) di atas, penutur memaksimalkan kesetujuan dengan mitra tutur. Tuturan tersebut terlihat bahwa guru berusaha untuk menyelamatkan perasaan hati siswa yang ditertawakan siswa lain dengan menghindari ketidaksepakatan dengan siswa tersebut. Guru berusaha untuk setuju dan memuji jawaban siswa walaupun jawaban siswa kurang tepat. Hal ini sesuai dengan indikator maksim kesetujuan Leech (1993: 217) yang menjelaskan dalam maksim kesetujuan harus memaksimalkan kesetujuan dengan mitra tutur.

Maksim simpati ini menuntut penutur untuk memaksimalkan kesimpatian terhadap mitra tutur dan meminimalkan antipati terhadap mitra tutur.

(6) Guru: "Tidak apa-apa, di diskusikan dulu, kalau masih belum ketemu jawabannya, disimpan dulu."

Data (6) Dituturkan guru ketika kelompok siswa presentasi tidak bisa menjawab pertanyaan yang dikemukakan siswa lain. Data (6) di atas, guru memaksimalkan kesimpatian kepada mitra tutur. Tuturan guru berusaha menyelamatkan perasaan siswa yang tidak bisa menjawab pertanyaan dengan mengatakan "tidak apa-apa". hal ini akan membuat siswa merasa senang karena mendapat dukungan dan perhatian lebih dari guru. Guru juga mengatakan "didiskusikan dulu, kalau masih belum ketemu jawabannya, disimpan dulu" untuk memberikan simpati kepada siswa. Tuturan simpati guru ini membuat siswa terselamatkan dari pertanyaan yang tidak bisa dijawab. Tuturan guru di atas telah memenuhi indikator yang dikemukakan Chaer (2010: 113) yaitu penutur memberikan simpati kepada mitra tutur.

\section{Strategi Kesantunan Berbahasa Guru dan Siswa dalam Proses Belajar Mengajar}

Brown dan Levinson (1987: 101-210) mengemukakan 25 strategi merealisasikan 
kesantunan berbahasa yang diklasifikasi atas kesantunan positif dan kesantunan negatif. Strategi kesantunan positif dirinci ke dalam lima belas subkategori sedangkan strategi kesantunan negatif sepuluh subkategori.

Strategi kesantunan berbahasa guru dan siswa yang ditemukan dalam penelitian ini adalah strategi kesantunan positif dan strategi kesantunan negatif. Strategi kesantunan positif ditemukan kategori yang terdiri dari (a) memperhatikan kesukaan, keinginan, dan kebutuhan mitra tutur; (b) melebihkan perhatian, persetujuan, dan simpati kepada mitra tutur; (c) mengintensifkan perhatian mitra tutur dengan pendramatisiran peristiwa atau fakta; (d) menggunakan penanda identitas kelompok (bentuk sapaan, dialek, jargon atau slang); (e) mencari persetujuan dengan topik yang umum atau mengulang sebagian atau seluruh tuturan; (f) menghindari ketidaksetujuan dengan pura-pura setuju, persetujuan yang semu, menipu untuk kebaikan, pemagaran opini; (g) menggunakan lelucon; (h) menyatakan paham atas keinginan mitra tutur; (i) memberi tawaran atau janji, (j) melibatkan penutur dan petutur dalam aktivitas; (k) memberi pertanyaan atau meminta alasan; (1) menyatakan hubungan secara timbal balik; dan (m) memberi hadiah (pujian) kepada petutur. Kemudian strategi kesantunan negatif ditemukan kategori yang terdiri dari (a) menggunakan ujaran tidak langsung, (b) menggunakan pagar, (c) bersikap pesimis, (d) meminimalkan tekanan, (e) memberi penghormatan, (f) meminta maaf, (g) menggunakan bentuk impersonal yaitu dengan tidak menyebutkan penutur dan lawan tutur.

Strategi kesantunan positif ini mengacu ke strategi bertutur dengan cara menonjolkan kedekatan, keakraban, hubungan baik di antara penutur dan mitra tutur. Penerapan subkategori strategi ini sebagai berikut.

Strategi memperhatikan kesukaan, keinginan dan kebutuhan mitra tutur. Penggunaan strategi ini penutur lakukan dengan cara memperhatikan kesukaan, keinginan, kelakuan, kebutuhan dan barang-barang mitra tutur termasuk memperhatikan fisik dari mitra tutur. Contoh data (7) di bawah ini, dituturkan ketika guru meminta bantuan siswa untuk menulis materi. Guru sebelum meminta bantuan terlebih dahulu memperhatikan dan memuji fisik dari siswa dengan mengatakan "ayu" untuk merealisasikan kesantunan dalam berbahasa.

(7) Guru: "Siapa yang tulisannya bagus? tolong bapak yaa.. Wulan bisa?" (sambil memandang siswi yang duduk paling depan)

Siswa:"Ini aja pak yang tulisannya bagus." (sambil mendorong temen sebangkunya) Guru:"Nah, ini yang ayu, tolong ya cah ayu bantu teman-temannya tuliskan di papan."

Strategi melebihkan perhatian, persetujuan dan simpati kepada mitra tutur. Penggunaan strategi ini dilakukan dengan memuji dan bersimpati secara berlebihan terhadap mitra tutur. Tuturan (8) dibawah ini, dituturkan ketika guru akan memulai pelajaran. Sebelum memulai pelajaran guru memuji siswa secara berlebihan untuk meningkat kegairahan siswa dalam proses belajar.

(8) Guru: "Cahaya yang terpancar dari wajah anda, senyum anda menandakan keikhlasan anda untuk belajar ya."

Siswa: "Amin" (serentak)

Strategi mengintensifkan perhatian pendengar dengan pendramatisiran peristiwa atau fakta. Penggunaan strategi ini dilakukan dengan cara meningkatkan ketertarikan terhadap objek yang sedang dibicarakan. Dalam tuturan (9) di bawah ini, dituturkan ketika guru mengkritik siswa yang berbicara kurang santun. Guru melalui tuturannya tidak hanya langsung mengkritik siswa tetapi berusaha meningkatkan ketertarikan siswa dengan memberikan contoh nada yang santun.

(9) Siswa 1: Hei Put

Siswa 2: Apa? apa? (dengan nada tinggi)

Siswa: Huuuuuu (siswa lain menyoraki karena mendengar jawaban dari siswa 2)

Siswa 2: Piye? (nada semakin tinggi)

Guru: Putri, jawabannya yang sopan dong, Ada apa? (mencontohkan dengan nada rendah). Bukan ada apa? (dengan nada tinggi). Nah tolong ya para siswa, diakhir kata itu nadanya turun jangan naik, seperti ini, "piye"? (mencontohkan dengan nada rendah) 
Siswa: (beberapa siswa menirukan nada yang dicontohkan guru)

Strategi menggunakan penanda identitas kelompok. Penggunaan strategi ini dilakukan dengan cara menggunakan penanda yang menunjukkan kesamaan identitas antar penutur dan mitra tutur. Data (10) di bawah, dituturkan guru ketika melihat siswa memainkan hp saat proses belajar berlangsung. Tuturan guru menggunakan kata "le" untuk memerintah siswa. Kata le adalah kata sapaan anak dalam bahasa jawa. Guru merealisasikan kesantunan berbahasa dengan menonjolkan kesamaan identitas daerah jawa.

(10) Guru: Hpnya disimpen dulu ya le, nanti kalau sudah selesai belajar baru dikeluarkan

Siswa : Iya pak

Strategi mencari persetujuan dengan topik yang umum atau mengulang sebagian atau seluruh tuturan. Penerapan strategi ini dilakukan dengan cara mengulang seluruh atau sebagian tuturan mitra tutur untuk menemukan persetujuan atau kecocokan. Tuturan (11) di bawah, dituturkan guru ketika membenarkan kata-kata dari siswa. Guru mengulang sebagian dari tuturan siswa untuk menunjukkan kesetujuannya dengan siswa.

(11) Siswa: "Maaf Pak, masih ada yang belum maju"

Guru: "Masih ada yang belum maju to, wah lali bapak."

Strategi menghindari ketidaksetujuan dengan pura-pura setuju, persetujuan yang semu, menipu untuk kebaikan, pemagaran opini. Penggunaan strategi ini dilakukan dengan cara menghindari ketidakcocokan dengan mitra tutur. Tuturan (12) di bawah ini, dituturkan guru memperbaiki kesalahan jawaban dari siswa. Guru berusaha untuk menghindari ketidaksetujuan dengan membenarkan jawaban siswa terlebih dahulu kemudian melakukan kritik terhadap jawaban itu.

(12) Siswa: "Terus juga seperti yang saya bilang sebelumnya dampak positif berikutnya itu, banyaknya korban itu kan menguntungkan bagi pihak rumah sakit" (siswa tertawa). Guru: "Gini para siswa, itu bisa juga ya, akan tetapi kita tidak boleh mengatakan itu dampak positif karena kita tidak boleh bersenang-senang di atas penderitaan korban"

Strategi menggunakan lelucon. Penggunaan strategi ini dilakukan dengan cara menggunakan lelucon atau tuturan yang mengandung humor. Tuturan (13) di bawah, dituturkan guru ketika melihat siswa tertidur saat proses belajar berlangsung. Guru menggunakan tuturan humor untuk meminta siswa bangun agar tuturan itu terasa lebih santun jika dibandingkan dengan tuturan perintah langsung.

(13) Guru: Fi, hati-hati lho ya, jangan tumpahkan semuanya"

Strategi menyatakan paham atas keinginan pendengar. Strategi ini menggunakan bentuk apersepsi bahwa penutur paham akan kondisi mitra tutur dan memahami keinginan mitra tutur. Data tuturan (14) di bawah, dituturkan ketika guru memberikan nasihat kepada siswa. Dalam memberikan nasihat guru terlebih dahulu mengerti atau menyatakan kepahamannya terhadap keinginan semua siswa.

(14) Guru: Menjadi hidup yang lebih baik, tapi tolong kamu jangan mementingkan harta di atas segala-galanya.

Strategi menawarkan atau berjanji. Strategi ini dilakukan dengan cara menyatakan janji kepada mitra tutur atau dengan cara menawarkan. Tuturan (15) di bawah, dituturkan guru ketika meminta siswa untuk maju presentasi. Guru melalui tuturannya menggunakan tawaran daripada menyuruh langsung siswa untuk maju presentasi. Hal ini akan mengurangi tekanan terhadap siswa.

(15) Guru : "Ayo, siapa lagi yang mau maju mempresentasikan silahkan. Daniel, Daniel mau? silahkan"

Strategi melibatkan penutur dan petutur dalam aktivitas. Strategi ini dilakukan dengan cara melibatkan mitra tutur dalam kegiatan yang akan dilakukan oleh penutur. Tuturan (16) di bawah, dituturkan guru ketika meminta siswa 
mendengarkan presentasi siswa lain. Guru menggunakan kata "kita" untuk menunjukkan kebersamaan dan akan mengurangi paksaan terhadap siswa.

(16) Guru: "Ayo kita dengarkan presentasinya temanmu"

Strategi memberi atau meminta alasan. Strategi ini dilakukan dengan cara meminta atau memberi alasan kepada mitra tutur. Tuturan (17) di bawah, dituturkan siswa ketika bertanya dalam presentasi kelompok siswa lain. Siswa dalam tuturannya menggunakan tuturan meminta alasan daripada langsung mengkritik materi presentasi siswa lain. Hal ini akan mengurangi rasa bersalah yang ada pada siswa yang presentasi.

(17) Siswa: "Apa itu peristiwanya terjadi dua kali atau ada yang salah penulisan?"

Strategi menyatakan hubungan secara timbal balik. Strategi ini dilakukan dengan cara menggunakan pola tindakan resiprokal yaitu penutur melakukan sesuatu sehingga mitra tuturpun harus melakukan sesuatu pula. Data tuturan (18) di bawah, dituturkan guru ketika akan menjelaskan materi yang sudah ditulis siswa. Guru mengunakan pola tindakan resiprokal, jika tidak ada yang bertanya, baru kemudian guru akan menjelaskan.

(18) Guru: "Ada yang mau bertanya dari yang sudah ditulis temannya, ayo yang bertanya silahkan. Kalau tidak ada bapak jelaskan sedikit."

Strategi memberi hadiah kepada petutur. Strategi ini dilakukan dengan cara memberikan hadiah, rasa simpati, pujian, atau kerjasama penutur kepada mitra tutur. Data (19) di bawah, dituturkan guru ketika memberi pujian kepada siswa yang berani maju presentasi. Guru dalam tuturannya memberikan hadiah atau pujian kepada siswa karena berani maju presentasi. Hal ini akan membuat siswa merasa senang dan bergairah untuk maju presentasi.

(19) Guru: "Ayo, silahkan kelompoknya agus" Siswa : "Siap pak"

Guru: "Bagus, harus berani seperti agus ya, sudah rapi, ganteng, pinter lagi."
Kemudian strategi kesantunan negatif merujuk ke strategi bertutur yang menunjukkan adanya jarak sosial di antara penutur dan mitra tutur. Penerapan subkategori strategi ini sebagai berikut.

Strategi menggunakan ujaran tidak langsung. Strategi ini dilakukan dengan menggunakan bentuk tuturan tidak langsung karena bagi orang indonesia penggunaan bentuk tuturan langsung dalam memerintah dianggap kurang sopan dibandingkan dengan menggunakan bentuk tuturan tudak langsung. Data (20) di bawah, dituturkan guru ketika melihat siswa tertidur saat pemutaran film selesai. Guru menggunakan ujaran tidak langsung untuk memerintah siswa agar bangun dari tidur.

(20) Guru: "Ayo Ardian, Eko filmnya sudah selesai."

Siswa: (bangun dan membuat siswa tertawa)

Strategi pertanyaan kalimat berpagar. Strategi ini dilakukan dengan menggunakan kalimat berpagar. Dikatakan berpagar karena ruang jawaban mitra tutur telah dibatasi oleh penutur oleh partikel-partikel tertentu seperti kalau tidak keberatan, kalau dimungkinkan, menurut pendapat kami, dan sebagainya. Data (21) di bawah, dituturkan guru ketika meminta siswa untuk menjenguk siswa lain yang tidak masuk. Guru memagari tuturannya dengan kata "kalau ada waktu" untuk memberikan perintah. Hal ini akan mengurangi paksaan terhadap mitra tutur.

(21) Guru: “...Dimas bagus kan sakit, nanti kalau ada waktu, tolong dijenguk ya supaya dia cepet sembuh bisa berkumpul lagi dengan para siswa."

Strategi bersikap pesimis. Strategi ini dilakukan dengan menggunakan kata-kata yang bermakna pesimis sebagai bentuk kesopanan. Data (22) di bawah, dituturkan siswa ketika diminta bercerita mengenai film yang pernah ditonton. Siswa dalam bertutur menggunakan nada pesimis untuk mengurangi kekecewaan yang akan dialami mitra tutur jika tidak sesuai dengan harapan. 
(22) Guru: "Ceritanya opo?"

Siswa: "Cerita pak? Tapi agak lupa pak"

Guru: "Tidak apa-apa bagian yang diingat saja"

Strategi meminimalkan tekanan. Strategi ini dilakukan dengan cara meminimalkan ancaman, rasa tidak senang atau tekanan kepada mitra tutur. Data (23) dituturkan guru ketika meminta perhatian siswa saat siswa sedang ribut. Guru dalam tuturannya menggunakan kata "tolong" dan "sebentar" untuk meminimalkan tekananan kepada siswa.

(23) Guru: "Sssttttt.... Tolong diperhatikan sebentar"

Strategi memberi penghormatan. Strategi ini dilakukan dengan cara memberikan penghormatan kepada mitra tutur. Data (24) dituturkan ketika siswa meminta ijin meninggalkan kelas. Siswa dalam tuturannya memberikan penghormatan kepada guru dengan menggunakan pilihan kata "ke belakang" untuk penghalusan kata dan siswa meminta ijin dulu sebelum meninggalkan ruangan.

(24) Siswa : "Permisi ke belakang pak"

Strategi meminta maaf. Dilakukan dengan cara menggunakan bentuk permohonan maaf sebagai strategi kesantunan. Data (25) di bawah, dituturkan guru ketika mengakhiri pelajaran. Guru dalam tuturannya meminta maaf kepada siswa jika ada yang tidak berkenan selama proses belajar berlangsung.

(25) Guru: "Sekian dari saya, bila ada kata yang tidak berkenan bapak mohon maaf,"

Strategi menggunakan Bentuk Impersonal yaitu dengan Tidak Menyebutkan Penutur dan Lawan Tutur. Strategi ini dilakukan dengan menggunakan bentuk impersonal sebagai bentuk kesantunan karena penggunaan penyebutan penutur maupun mitra tutur dianggap kurang santun. Data (26) dituturkan ketika siswa sedang ribut saat menulis materi. Guru dalam tuturannya menggunakan bentuk impersonal dengan tidak menyebut siswa sebagai mitra tuturnya dan guru sebagai penutur. Hal ini akan mengurangi tekanan pada siswa sebagai mitra tutur.
(26) Guru: "Serius tolong ya, jangan ada yang bercanda, setelah ini dijelaskan"

Fungsi Kesantunan Berbahasa Guru dan Siswa dalam Proses Belajar Mengajar

Fungsi kesantunan guru dan siswa dalam proses belajar mengajar yang ditemukan dalam penelitian adalah fungsi menyatakan, menanyakan, memerintah, meminta maaf dan mengkritik. Hal ini sesuai dengan fungsi pertuturan yang dikemukakan Chaer (2010: 7999). Fungsi kesantunan ini diuraikan sebagai berikut.

Fungsi menyatakan di dalam kajian gramatikal dilakukan dalam bentuk kalimat deklaratif, yakni kalimat yang hanya menyampaikan berita atau kabar tentang keadaan di sekeliling penutur. Tuturan dalam kalimat deklaratif ini penutur tidak mengharapkan adanya komentar dari lawan tutur. Namun, bukan berarti lawan tutur tidak boleh mengomentarinya. Data (27) di bawah, dituturkan siswa ketika menanggapi permintaan dari guru. Siswa dalam tuturannya memiliki fungsi untuk menyatakan bahwa teman sebangkunya lebih bagus dalam hal menulis. Hal ini dilakukan siswa untuk menolak permintaan guru secara halus.

(27) Guru: "Siapa yang tulisannya bagus? Tolong bapak yaa.. Wulan bisa?" (sambil memandang siswi yang duduk paling depan) Siswa: "Ini aja pak yang tulisannya bagus"

Tuturan dengan fungsi menanyakan dilakukan dengan kalimat bermodus interogatif. Ciri utama tuturan ini adalah adanya intonasi naik di akhir kalimat. Data (28) di bawah, dituturkan guru ketika mengontrol jalannya proses pembelajaran. Guru dalam tuturannya mencoba untuk memberikan perhatian kepada siswa dengan menanyakan keadaan dari siswa tersebut.

(28) Guru: "Gimana kabarnya cantik sehat?" Siswa: "Sehat pak"

Tuturan dengan fungsi memerintah dilakukan dengan kalimat bermodus imperatif. Tuturan dengan fungsi memerintah ini menginginkan agar mitra tutur melaksanakan isi tuturan tersebut. Data (29) di bawah, dituturkan guru ketika siswa menjawab pertanyaan dengan 
suara yang kecil. Dalam tuturannya guru memerintah siswa untuk memperbesarkan suara karena tidak terdengar dengan jelas. Dalam hal ini guru menggunakan kalimat tanya untuk memerintah siswanya.

(29) Guru: "Bisa ulangi lebih keras lagi?" (mendekatkan tangan kirinya ke telinga seolah-olah agar suara siswa lebih jelas terdengar)

Tuturan dengan fungsi meminta maaf dilakukan oleh penutur karena penutur merasa punya salah atau telah dan akan melakukan ketidaknyamanan terhadap mitra tutur. Data (30) di bawah, dituturkan siswa ketika terlambat memasuki kelas. Siswa dalam tuturannya meminta maaf karena sudah melakukan kesalahan. Selain kesalahan terlambat masuk kelas, siswa juga mengganggu jalannya pembelajaran ketika memasuki kelas.

(30) Siswa: "Maaf terlambat pak"

Fungsi mengkritik ini dilakukan dengan menyebutkan keburukan, kekurangan, kekeliruan dan kesalahan yang dimiliki mitra tutur. Data (31) di bawah, dituturkan guru ketika siswa selesai menyanyikan lagu wajib saat pelajaran akan dimulai. Guru dalam tuturannya mengkritik sikap siswa ketika menyanyikan lagu Indonesia Raya. Guru mengkritik dengan menyebutkan kesalahan yang ada pada siswa, kemudian melakukan nasihat kepada siswa.

(31) Guru: "Para siswa tolong ya, besok kalau menyanyikan lagu Indonesia raya, tolong tangannya jangan ke belakang, caranya harus sikap siap, masak tangannya ke belakang."

\section{SIMPULAN}

Wujud pematuhan prinsip kesantunan berbahasa pada tuturan guru dan siswa dalam proses belajar mengajar bahasa Indonesia kelas XI SMKN 2 Depok Sleman telah menerapkan pematuhan maksim kesantunan yaitu kebijaksanaan, kedermawanan, pujian kerendahhatian, kesetujuan, dan simpati. Selain pematuhan satu maksim, dalam tuturan guru juga telah menerapkan dua maksim sekaligus, yaitu pematuhan maksim kebijaksanaan dan pujian, maksim kebijaksanaan dan kedermawanan, maksim kebijaksanaan dan simpati, maksim kebijaksanaan dan kesetujuan, maksim kedermawanan dan kerendahhatian, terakhir maksim pujian dan kerendahhatian. Pematuhan maksim kebijaksanaan mendominasi pada tuturan guru dan siswa. Hal ini dikarenakan tuturan guru berusaha mengurangi kadar kerugian yang akan dialami siswa sebagai mitra tutur guru ketika memberikan perintah, ini bertujuan agar siswa tidak merasa terpaksa atau terbebani akibat efek tuturan perintah guru. Secara tidak langsung hal ini juga membuat suasana kelas menjadi nyaman bagi siswa untuk belajar karena pengurangan kadar kerugian dan tekanan pada siswa yang lebih banyak menjadi sasaran dalam tuturan perintah guru.

Strategi kesantunan berbahasa pada tuturan guru dan siswa dalam proses belajar mengajar bahasa Indonesia kelas XI SMKN 2 Depok Sleman telah menerapkan strategi kesantunan positif dan negatif. Penerapan strategi kesantunan negatif dengan kategori meminimalkan tekanan mendominasi dalam tuturan guru dan siswa. Hal ini dikarenakan guru ingin meminimalkan tekanan kepada siswa untuk membuat siswa lebih nyaman di dalam kelas. Hal ini terjadi akibat lebih seringnya guru menggunakan tuturan perintah, yang dimana dalam tuturan perintah akan membatasi kebebasan yang dimiliki siswa untuk melakukan sesuatu. Hal ini akan berdampak pada pilihan guru untuk menggunakan strategi kesantunan dalam bertutur dengan siswa.

Fungsi kesantunan berbahasa pada tuturan guru dan siswa dalam proses belajar mengajar bahasa Indonesia kelas XI SMKN 2 Depok Sleman, muncul beberapa fungsi yaitu fungsi menyatakan, fungsi menanyakan, fungsi memerintah, fungsi meminta maaf dan fungsi mengkritik. Fungsi memerintah merupakan fungsi yang paling banyak muncul dalam interaksi belajar mengajar. Hal ini dikarenakan guru bertanggung jawab untuk mengontrol dan mengkondusifkan jalannya proses belajar mengajar sehingga menjadi lancar dan nyaman bagi siswa. Untuk mengujudkan hal itu, guru lebih banyak menggunakan tuturan dengan fungsi memerintah untuk mengontrol jalannya proses belajar mengajar. Tuturan dengan fungsi memerintah ini tentunya harus menerapkan 
kesantunan berbahasa dalam menuturkannya. Fungsi memerintah ini banyak ditemukan penanda kesantunan mari, tolong, ayo, silahkan, dan coba sebagai penanda kesantunan berbahasa dalam merealisasikan kesantunan berbahasa.

\section{DAFTAR PUSTAKA}

Aziz, A. 2005. Konsep Wajah dan Fenomena Kesantunan Berbahasa Pada Masyarakat Cina Modern: Kasus Shanghai. Jurnal Ilmiah Masyarakat Linguistik, 23 (2), 205-214.

Brown, P., \& Levinson, S.C. 1987. Politeness Some Universal in Language Usage. Cambridge: Cambridge University Press.

Chaer, A. 2010. Kesantunan Berbahasa. Jakarta: Rineka Cipta.

Halim, H., Kaseng, S., Taha, Z., \&Hamsa, A. 2015. Politeness in Buginese Language as a Social Status Symbol in Wajo Regency. Journal of Language Teaching and Research, 6 (1), 230-239.

Kumar, N.U,. Philip, P,. \& Kalaiselvi, A. 2013. The Application of CLT to Teaching English as a Second Language - an Assessment of Practice In India. International Journal of Humanities and Social Science Invention. 2 (5), 24-29.
Leech, G. 1993. Prinsip-Prinsip Pragmatik (terjemahan M.D.D. Oka). Jakarta: Universitas indonesia Press.

Mahsun. 2005. Metode Penelitian Bahasa. Jakarta: Rajawali Pers.

Malhari, B.D. 2015. Importance of Politeness Principle. International Journal of Muluifaceted and Multilingual Studies, I (VII), 1-8.

Pranowo. 2012. Berbahasa Secara Santun. Yogyakarta: Pustaka Pelajar.

Rahadini, A., \& Suwarna, S. 2014. Kesantunan Berbahasa dalam Interaksi Pembelajaran Bahasa Jawa di SMP N 1 Banyumas. LingTera, 1(2), 136 - 144. Retrieved from http://journal.uny.ac.id/ index.php/ljtp/article/view/2591.

Rahardi, K. 2007. Pragmatik: Kesantunan Imperatif Bahasa Indonesia. Jakarta: Gramedia Pustaka Utama.

Watts, R, J. 2003. Politeness. Cambridge: Cambridge University Press.

Zamzani, Musfiroh, T., Maslakhah, S., Listyorini, A., \& Eny, Y. 2011. Pengembangan Alat Ukur Kesantunan Bahasa Indonesia dalam Interaksi Sosial Bersemuka dan Nonbersemuka. Jurnal LITERA, 10 (1), 35-50. 